\title{
Juvenile Xanthogranuloma
}

National Cancer Institute

\section{Source}

National Cancer Institute. Juvenile Xanthogranuloma. NCI Thesaurus. Code C3451.

A benign histiocytic tumor that occurs during childhood; it is distinct from Langerhans cell histiocytosis. It is characterized by the presence of lipid-laden, foamy histiocytes and Touton-type giant cells in the dermis. The lesions usually develop during infancy. They consist of cutaneous papules and nodules (most often in the head and neck). It is sometimes associated with deep soft tissues nodules. 